\title{
Introduction to part IV
}

\author{
Diane Whitehouse \\ Scientific Officer \\ ICT for health - European Comission \\ diane.whitehouse@ec.europa.eu
}

As human beings, we often like to ponder theory in a void. However, there is nothing more challenging that considering ethics in practice. This conference did not veer away from that challenge. Here the stimulus has been to choose two of the most important issues underlying today's Information Society - eHealth and eLearning firstly, in whatever healthcare context that provision takes place and, secondly, whether that education occurs in the school, university, or pre-occupational context. These are the very precise 'applied issues' to which this chapter is directed.

eHealth is one of the mainstays of the Information Society. Since the 1960s initially, but particularly in the last decade and a half, eHealth has emerged from the domain of research and development into concrete deployment. Institutions and countries have dedicated more than a thousand million euros over more than a fifteen-year period to supporting research in this field (Olsson, Lymberis, and Whitehouse, 2004). The eighteen-step eHealth action plan published in a Communication of 2004, is now more than halfway complete (European Commission, 2004). The vast majority of the current Member States (European Commission, in press) now have eHealth strategies and actions. The Member States themselves are today exploring how to bring together their so far rather fragmented initiatives, challenged as they are by numerous provocations to provide good, accessible, high-quality, but also cost-effective eHealth (see eHealth conference 2007).

In a climate in which the provision of healthcare - especially cross-border throughout Europe - is being raised, this enhanced, sophisticated provision of systems and services begins to pose a set of questions that pertain to the legal and regulatory context surrounding eHealth. Efforts are currently underway to ascertain precisely what the key issues are - at a minimum, they cover data protection, product and service liability, and trade and competition (Herveg et al, in press). A particularly innovative approach can be to outline these provocative questions in the form of a series of case-studies or scenarios - this is the basis of the Legally eHealth study. Here, however, Herveg and Poullet follow a more conventional and lawyerly 
approach: they undertake a systematic testing of the main uses of eHealth against four independent criteria and, in particular, they draw on the work of the European Union's Data Protection Directive. They appropriately remind us, however, that many different stakeholders are involved in the eHealth debate: certainly, it includes many different health occupations but also patients and citizens themselves. All will require having a greater voice in discussing the mechanism of the 'trust circle' that surrounds the electronic health or medical record.

eLearning has also been at the heart of the development of the Information Society. Information and communication technologies have transformed the face of Europe's education systems. While twenty years ago, microcomputers were slowly being introduced into all three levels of education (Hirschheim, Smithson, and Whitehouse, 1990, p12), that shift is now complete at least in the mainstream of the European Union. But we should not forget that computers are all too often only available largely to those with wealth, privilege, and education (Demunter, 2006).

The debate has become not so much about what, why or even how to teach computing skills but rather to teach it according to what underlying ethics? Neal's and Martens' two chapters provide very different solutions to introducing ethics into the teaching of computing. On the one hand, Neal tells the story of a codified approach, agreed to by a professional society over a considerable period of time, and complied with by the universities and relevant departments which are happy to be accredited in recognition of the quality and content of their programmes. Martens, on the other hand, outlines an approach which would appear to be at a more preliminary, even grassroots stage: creative, stimulating, and which uses new methods and methodologies - a more patchwork or bricolage-style approach. Not only are the secondary school children with whom Martens' teacher-trainees deal much younger than Neal's university students, but they are also ostensibly more adventurous and exploratory. With Martens, we are firmly embedded in the the notion that ethics can surely be approached and taught through dialogue and debate (Whitehouse and Duquenoy, 1998).

While these chapters draw on the work of researchers and scholars, one of the striking results of the dialogue that surrounded this conference's work was the meaning of computing in an applied setting, whether in eHealth or eLearning. Given that the conference attendees were indeed celebrating the work of an intellectual lifetime of a noted researcher and academic, one of the most thrilling interactions of the two days were the discussions with local people from the Namur area and with employees working in local Namurois and Walloon government. This mix of careers and backgrounds made for stimulating and challenging discussions about precisely what the Information Society means to us, to our families, to our children. It forced the academics present to acknowledge the benefits of creating such a heterogeneous mix of conference and workshop attendee. This kind of cross-disciplinary, crosssectional, and cross-societal approach is one that is firmly held to by the Computers and Social Accountability working group, and especially one which underpins not only its working conferences but also its regular summer schools (Beardon and Whitehouse, 1990; Zielinski, Duquenoy, and Kimppa, 2006).

Finally, while it may appear curious that two out of the three chapters collected here come from Belgium, and the other from the United Kingdom, it is not so surprising since these two countries have long and established histories of concerns 
for legal, regulatory, and ethical issues in the domains supporting the Information Society. Particularly where the notion of professionalism is concerned, the United Kingdom has an established context analysed in several of the International Federation for Information Processing (IFIP) books (e.g., Zielinski, Duquenoy, and Kimppa, 2006). Indeed, the man in whose honour the conference was launched is himself Belgian and has developed long and stimulating intellectual relationships with the Anglophone world. May Jacques Berleur's devotion to Computers and Social Accountability remain long a very dynamic source of stimulus and inspiration for events and dialogues such as this!

\section{References}

Beardon, C. and D. Whitehouse (1990) Computers and Society: Citizenship in the information age. Intellect Press: Oxford.

Demunter, C. (2006) How skilled are Europeans in using computers and the Internet? Statistics in focus. Luxembourg: European Commission. 17 (2006).

eHealth conference 2007:

http://ehealth.gvg-

koeln.de/xpage/objects/eh07_ankuendigung/docs/4/files/Flyer_eHealthweek_english .pdf

European Commission (2004) e-Health - making healthcare better for European citizens: An action plan for a European e-Health Area. COM (2004) 356.

European Commission (in press) eHealth strategies and implementation in European countries.

Herveg, J., Silber, D., van Dooselaere, C., Vereerken, I., and P. Wilson (in press), A conflict of interests? Understanding the legal duty of confidentiality in eHealth within European Law. e-Services Journal.

Hirschheim, R., Smithson, S. and D. Whitehouse (1990) Microcomputers and the Humanities:

Survey and Recommendations. Ellis Horwood Limited: Chichester.

Legally eHealth:

http://istresults.cordis.europa.eu/index.cfm/section/news/tpl/article/BrowsingType/Fe atures/ID/88830

Olsson, S., Lymberis, A., and D. Whitehouse (2004) European Commission activities in eHealth. International Journal of Circumpolar Health. 63 (4), 310-316 
Whitehouse, D. and P. Duquenoy (1998) The process of ethics. In Computer and Networks in the Age of Globalization. IFIP TC9 Fifth World Conference on Human Choice and Computers, August 25-28, 1998, Geneva, Switzerland, edited by Rasmussen, L.B., C. Beardon, and S. Munari. Kluwer Academic Publishers: Boston/Dordecht/London, pp361-379.

Zielinski, C., Duquenoy, P. and K. Kimppa (2006) The Information Society: Emerging Landscapes. 